Article

\title{
Perceptions, Resentment, Economic Distress, and Support for Right-Wing Populist Parties in Europe
}

\author{
Diogo Ferrari \\ Department of Political Science, University of California - Riverside, USA; E-Mail: diogo.ferrari@ucr.edu
}

Submitted: 23 December 2020 | Accepted: 3 June 2021 | Published: 27 August 2021

\begin{abstract}
Research has demonstrated that resentful emotions toward the politics and perceptions of being culturally and economically threatened by immigration increase support for populist parties in some European countries, and that macro-level economic conditions engender those perceptions and emotions and increase populist support. This article reveals that household-level economic conditions also affect perceptions that immigrants represent a threat to a country's culture and economy. Low- and middle-income populations are more vulnerable to suffer economic distress due to macro-level factors such as import shock, which can increase their resentment toward democracy, and their perceptions that immigration is a cultural and economic threat, therefore increasing the likelihood to vote for populist parties. A mediation analysis using the European Social Survey data from 2002 to 2018 provides evidence for the argument.
\end{abstract}

\section{Keywords}

economic conditions; economic distress; populism; voting behavior

\section{Issue}

This article is part of the issue "Reactionary Politics and Resentful Affect in Populist Times" edited by Tereza Capelos (University of Birmingham, UK), Stavroula Chrona (King's College London, UK), Mikko Salmela (University of Helsinki, Finland / University of Copenhagen, Denmark), and Cristiano Bee (Oxford Brookes University, UK).

(C) 2021 by the author; licensee Cogitatio (Lisbon, Portugal). This article is licensed under a Creative Commons Attribution 4.0 International License (CC BY).

\section{Introduction}

Support for populist parties grew substantially in some European countries since the 2000 s. In France, only $3 \%$ of people interviewed by the European Social Survey (ESS) declared that they voted for right-wing populists in 2008. That number grew to $13 \%$ in 2016 . This represents an increase of $333 \%$ in populist support. Five percent of Austrian respondents reported that they had supported those parties in 2004, but that number jumped to $20 \%$ by 2016 , which represents a $300 \%$ growth in right-wing populist supporters in that country. From 2008 to 2016, Finland's support for right-wing populists grew from $4 \%$ to $15 \%$, a $270 \%$ increase. Although there are countrylevel variations, this seems to be an overall trend across various countries in Europe (Rooduijn et al., 2019).

At the micro-level, a quick look at the data available from the ESS reveals a persistent pattern across European countries in which the proportion of vot- ers that support populist parties decreases with family income. For instance, the bivariate association between families' income and vote for populist parties has been negative in Germany, Finland, Ireland, Denmark, Poland, Switzerland, Austria, and many other countries since 2002. This article focuses on the micro-level foundations of populist support and investigates whether family-level economic conditions help explain support for right-wing populism and, if so, why?

At first glance, the association between families' income and support for right-wing populist parties seems puzzling because many studies argue that individual and family-level economic conditions are irrelevant after we take into account other factors related to perceptions, beliefs, and emotions. Various authors have demonstrated, for instance, that right-wing populist parties in Europe find support among sectors of the population that feel threatened economically (Lubbers \& Scheepers, 2002; Lucassen \& Lubbers, 2012) and 
culturally (Ivarsflaten, 2005) due to changes in their social and economic environment, aggravated by the flux of capital and labor across the borders. Hence, according to this perspective, it is the perception of being culturally and economically threatened by immigrants that explains electoral support for right-wing populists, and the explanatory power of families' income disappears after we take those factors into account (Mutz, 2018). Other authors have shown that right-wing populist parties profit electorally from affective reactions that emerge in such an uncertain environment, including dissatisfaction with, distrust of, and resentment toward the status quo, political elites, and established institutions (Betz, 1994, 2009; Capelos \& Demertzis, 2018; Capelos \& Katsanidou, 2018). Right-wing populist parties and candidates present themselves as challengers to the current state of affairs, as nationalists who are anti-elite, pro-market, anti-state intervention, and anti-immigration (Betz, 1993; Mudde, 2010; Mudde \& Kaltwasser, 2017), attracting voters who are resentful of the status quo and feel threatened culturally and economically. Hence, one may conclude that resentment and perceptions of cultural and economic threat are the main driving forces, and economic conditions at the micro-level become irrelevant once we consider those factors.

In this article, we challenge this conclusion by taking a different approach. Conventional approaches investigate objective conditions (e.g., family income) against subjective factors, such as emotions and perceptions. Instead, we investigate a causal chain connecting familylevel economic conditions and vote for right-wing populist parties. We argue that as families' economic conditions decline, feelings of resentment at the status quo, and perceptions that immigrants represent an economic and cultural threat to the country, increase. These perceptions and resentment, then, affect support for rightwing populism. In other words, we argue that perceptions of cultural and economic threat and resentment at the status quo mediate the effect of family economic conditions on vote for populists. It is not surprising, then, that the effect of family-level economic conditions may disappear when one controls for emotions and perceptions. It is not that these objective conditions don't matter, but that they matter in great part indirectly.

This argument is not new, but it has not received the attention it deserves nor the empirical treatment it requires. In that sense, this article contributes to the literature on causes of populist support, first, by integrating the three explanations mentioned above-resentment and perceptions of cultural and economic threat-and proposing that they work as a causal mechanism connecting family-level economic conditions and support for populism. Those feelings and perceptions affecting populist support may have other origins, but we argue that they are also significantly affected by families' economic conditions. More precisely, the argument is that economic hardship affects people's perceptions of cul- tural threats and economic insecurity, fuels resentful emotions and, through those perceptions and emotions, increases support for populist parties. That causal chain is evaluated using a mediation analysis, which provides the empirical treatment the argument requires.

The second contribution of the article is that this approach reconciles two simple facts that consistently appear in opinion surveys and previous literature: The first is the role of emotions, beliefs, and perceptions on populist support (Capelos \& Demertzis, 2018; Capelos \& Katsanidou, 2018). The second is that those resentful affects and perceptions are not equally distributed across socioeconomic groups (Betz, 1993, 2009; Lucassen \& Lubbers, 2012). Resentment toward the status quo and perception of being economically and culturally endangered are higher among low- and middleincome groups than among the high-income population. We argue that low-income groups become more susceptible to populist appeals to the extent that they are also more likely to feel more vulnerable, threatened, and resentful toward the current configuration.

Using the ESS data from 2002 to 2018, this article shows that, on average, around $55 \%$ of the effect of families' income on the propensity to vote for right-wing populist parties is mediated by the effect of the former on feelings of resentment at the status quo and perceptions of being culturally and economically threatened by immigrants. In other words, $55 \%$ of the effect of families' income on populist vote occurs because income affects resentment and perceptions. When we control for the effect of macro-level economic conditions, such as regional-level unemployment, import shocks, inflow of immigrants, and regional trade balance, that mediation effect remains close to $50 \%$.

\section{Literature Review}

Support for populist parties is often associated with a combination of economic conditions such as stagnation, unemployment, import shock linked to globalization, and perception of economic deprivation (Colantone \& Stanig, 2018, 2019; Margalit, 2019; Mayda, 2006; Rodrik, 2018). Other authors point to the effect of cultural grievances and perceptions that a person's social status is under threat (Hainmueller \& Hiscox, 2007; Mutz, 2018; Sniderman et al., 2004, 2007) or to reactionist attitudes fueled by resentful affectivity toward the status quo, political elite, and other groups (Capelos \& Demertzis, 2018; Capelos \& Katsanidou, 2018). Let us consider the resentful affectivity argument first.

\subsection{Resentful Affect}

Right-wing populist parties find support among citizens who developed a bundle of anti-immigrant, anti-EU, anti-political elite sentiments whose core, at the emotional level, can indicate a resentful reaction toward the current state of affairs (Capelos \& Demertzis, 2018; 
Capelos \& Katsanidou, 2018). The concept of resentful affect, or resentment, as used here refers to an emotional reaction that can be expressed as a pure dissatisfaction with an object or idea. Demertzis (2006) and Capelos and Demertzis (2018) discuss the concept of resentful affect and ressentiment and their relation to anti-immigrant sentiments. While resentment can be about a moral anger, ressentiment refers to compensatory emotions that couple with frustrations due to feeling powerless in the face of unfavorable events. The concept of resentful affect in this article is closer to those definitions but focuses on the expression of dissatisfaction associated with those emotional reactions. Right-wing populist parties reinforce people's resentment at the way their polity operates, as well as the anti-attitudes connected to that sentiment, and profit electorally from it because they present themselves as guardians of the national identity and economic interest against immigrants, foreign government demands, and domestic corrupted elite (Golder, 2003; Mudde, 2007).

Studies show that these feelings are amplified in contexts of economic hardship at the micro- and macrolevels. They are more common among some socioeconomic groups that feel less powerful to change the course of events (Capelos \& Demertzis, 2018) and are more vulnerable and likely to suffer economic deprivation (Semyonov et al., 2006). According to these findings, resentment is not randomly distributed among economic strata, and even though it can occur across income lines, it is less likely to emerge among those who are more well-off in society, to the extent that economic deprivation is less likely to reach them.

If it is the case that (1) higher resentment at the way the polity operates increases the likelihood of voting for right-wing populist parties, and (2) families that are more well-off are less likely to develop those resentful emotions, then it must be the case that families' economic conditions affect support for populist parties due to its effect on resentful affect. But resentful affect at the status quo does not mediate the effect of economic conditions alone. It does so in combination with perceptions of economic and cultural threat, especially toward immigrants in the European context.

\subsection{Cultural Threat}

One of the main theses about the emergence of rightwing populist parties emphasizes electoral support from those who feel culturally threatened or left behind. We use these terms broadly and interchangeably to represent the perception that one's values, beliefs, and lifestyle are threatened due to contact with out-group members. This contact is perceived as a cultural or status threat if the out-group members or their social status grows in number or importance (Mutz, 2018; Semyonov et al., 2004).

One mechanism that can trigger cultural threat is the economic and social changes associated with mod- ernization (Inglehart, 1997; Minkenberg, 2000; Mudde \& Kaltwasser, 2017). The cultural aspect of the modernization argument says that modernization favors the emergence of post-materialist values of multiculturalism, racial and gender equality demands, sexual freedom, individualism, and a rupture with previously established social hierarchies and authority (Golder, 2016; Inglehart, 1997; Minkenberg, 2000). It leads to an attitude backlash among those who previously maintained high social status and hold values whose validity is being challenged.

In recent years, much attention has been given to the effect of immigration on perception of threat to cultural dominance by some non-immigrant subpopulations in Europe. Various studies show that attitudes toward immigrants are consistently associated with support for rightwing populist parties that defend nativism and nationalism. Some researchers say that right-wing extremists and populist parties would not have been successful without mobilizing those grievances over immigration (Ivarsflaten, 2008; Lubbers et al., 2002; Norris, 2005).

The social identity (Tajfel \& Turner, 2004; Turner \& Tajfel, 1986) and group conflict theories provide theoretical justifications for why some groups feel culturally threatened. According to the group conflict argument, society is characterized by a competition between identity or ethnic groups to establish dominance over material resources and social values (Coser, 1956). Blalock (1967) differentiates between actual and perceived competition, and states that actual competition affects majorities' perceptions of competitive threats from out-group members, producing hostility toward them. Scheepers et al. (2002) connect this argument to social identity theory, which states that in-group members tend to perceive their group as superior, attribute in-group characteristics to themselves, and negatively value out-group members. As a result of perceived competition and an in-group desire for in- (or out-)group characteristics to dominate (or be avoided), the perception of cultural threat intensifies if immigration becomes a salient issue, which causes attitudes of ethnic exclusionism to increase (Scheepers et al., 2002). As the argument goes, immigration and an influx of a culturally-alien population, which results from modernization and globalization, leads to feelings of loss of national identity, and seeds reactionary tendencies among those who feel culturally threatened, increasing support for populist parties in that sub-population (Koopmans et al., 2005; Norris, 2005). Some authors have highlighted that a similar phenomenon happened in the US, but the population that is growing in number and status is Black Americans, not only immigrants, raising perceptions of status threat for some white subgroups and increasing their propensity to vote for candidates that represent the reestablishment of those threatened hierarchies (Mutz, 2018).

Ultimately, it is the perception rather than the actual cultural threat that matters, but the actual competition over resources fuels the perception of cultural threat (Blalock, 1967; Scheepers et al., 2002) and can increase 
populist support. Previous research has demonstrated that regional-level import shocks can trigger xenophobic beliefs (Hays et al., 2019) and, through those beliefs, populist support increases. Other authors have demonstrated that occupation and social class have a similar effect, impacting perceptions of cultural and economic threat, and therefore populist support (Lucassen \& Lubbers, 2012). This article builds on that literature and investigates if this type of mediation effect, where perception of cultural threat due to immigrants mediates the effect of socioeconomic variables on support for populism, also occurs at the level of individual and family economic conditions.

\subsection{Economic Threat}

Alongside resentment at the status quo and perceived cultural threat due to immigration, authors have investigated if populist support is prevalent among those who feel economically threatened or left behind economically. It is important to distinguish between a person's actual economic circumstances and their perception of being under economic threat or competing for economic resources. This distinction is theoretically relevant and has methodological implications, as we will discuss briefly below and in detail in the next section.

Changes in the economic environment and perceptions of economic vulnerability are connected, and both can affect voting behavior. Modernization, globalization, and group conflict theory provide theoretical justifications for why feelings of economic insecurity can increase electoral support for right-wing populists instead of other parties with different political positions, such as those that favor welfare programs. The economic aspect of the modernization argument points that some are left behind during the modernization process because they do not possess the human capital and skills to "obtain the standard of living they would have enjoyed in the past" in the post-war industrial period (Golder, 2016, p. 482; see also Betz, 1994). Some right-wing populist parties profit from these grievances by promising a return to an abstract and idealized moment of prosperity and order in the past (Capelos \& Katsanidou, 2018).

Two of the main arguments in the recent debate about populist support emphasize the role of globalization and immigration. Salience and intensification of trade and immigration in the context of a globalized economy can cause anti-immigration sentiments or increase support for nationalist anti-immigration rightwing parties if they trigger perceptions that immigrants compete for job positions and drain welfare resources (Colantone \& Stanig, 2018). Additionally, realist group conflict theory provides a justification for why this can lead to anti-immigrant sentiments: a conflict of economic interests between immigrants and nationals that compete for scarce economic resources (Hardin, 1997). This conflict can lead to a perception that immigrants represent an economic threat. Authors have shown, for instance, that actual economic decline, such as regionallevel trade-induced economic shocks, affect right-wing support because they affect sociotropic economic concerns and attitudes toward immigrants (Hays et al., 2019). Hence, those attitudinal and subjective factors mediate the effect of actual economic conditions on populist support.

One issue with the subjective factors that mediate the effect of actual economic conditions on vote is that they are strongly correlated (Sniderman et al., 2004, 2007) and can causally affect each other. For instance, sentiments of economic insecurity can fuel resentment at the status quo or perceptions of cultural threat, and vice-versa. This mutual determination between perceptions and affect can pose some challenges for empirical analysis of how they mediate the effect of economic conditions. The next section discusses a strategy to investigate this question.

\subsection{The Mediation Effect of Resentment and Perceptions of Cultural and Economic Threat}

We can draw two conclusions from the previous sections. First, it is not easy to disentangle feelings of resentment at the status quo and perceptions of cultural and economic threat, especially in observational data. Although actual economic conditions and immigration can be exogenous factors, the subjective dimensions of perception of economic insecurity, cultural threat, and resentful affect are endogenous. Resentment can emerge due to perceptions of being left behind culturally and economically, especially among those who are more vulnerable. Conversely, resentment can intensify perceptions of cultural and economic threat if it is fed by other sources, such as feelings of political inefficacy (Capelos \& Demertzis, 2018; Capelos \& Katsanidou, 2018). The same goes for the relationship between the perception of economic and cultural threat. Some studies have considered those two dimensions separately and evaluated their relative importance to explain populist success or anti-immigrant attitudes (Ivarsflaten, 2008; Lucassen \& Lubbers, 2012; Mutz, 2018; Sniderman et al., 2004, 2007). However, empirical measures of those two factors are highly correlated and, more importantly, they can cause each other. Perceptions that immigrants compete for jobs or are bad for the economy can lead to animosities that are expressed in terms of cultural threat, and vice-versa. Hence, empirical analyses must take into account this endogeneity between these three dimensions; namely, resentment, and perception of cultural and economic threat.

The second conclusion is that, at the micro-level, economic factors matter for populist support because they affect a person's resentment and perceptions of cultural and economic threat. That is, these elements matter because they mediate the effect of economic conditions on populist support. Although there is strong evidence that regional-level factors (such as trade-induced eco- 
nomic shocks) matter (Colantone \& Stanig, 2018; Hays et al., 2019), there are mixed findings that individual-level economic conditions affect populist support (Ivarsflaten, 2005; Koopmans et al., 2005; Mutz, 2018). Some studies in the US show that family income is not associated with support for Trump (Mutz, 2018), but a series of studies demonstrate that high-income individuals are less likely to support populists (Hays et al., 2019; Rydgren \& Ruth, 2013; Werts et al., 2013). How should we understand this mixed evidence on the effect of family-level economic conditions, in particular income levels, with regards to support for right-wing populist parties?

The key to understand the role of individual- or household-level economic conditions on populist support is through its effect on resentment and threat perception. The main argument of this article is that the perceptions of sociocultural and economic threat and resentful affect are not equally distributed across income groups. Those more vulnerable relate differently to the economic environment when compared to the affluent population. They are more exposed to suffer the economic consequences of economic downturns and feel threatened by the influx of immigrants. We can state that hypothesis as follows: Individual- or householdlevel economic hardship affects support for populist parties because they increase perception of sociocultural threat from immigrants and fuel resentful affect toward the status quo.

Although scholars have considered that type of mediated effect for regional-level economic shocks (Hays et al., 2019) and class occupation (Lucassen \& Lubbers, 2012), the same has not been done for personal or family economic conditions. Moreover, resentful affect as a mediator of families' economic conditions has not been fully integrated into this type of mediation analysis.

One difficulty with this argument is that, because the three mediators-resentful affect and perceptions of cultural and economic threat-mutually affect each other, we cannot use them separately in the mediation analysis nor control for them separately, 'in parallel,' unless we can ensure their exogenous variation through manipulation or find intermediate variables that "block" their causal connection. In other words, the mediation effect is not identifiable if we use those three variables in parallel or separately with observational data. A possible identification strategy is to use them jointly as if they represented a single subjective state of resentment-threat perception (Park \& Esterling, 2020). Figure 1 contains a diagram that captures this solution. The resentment-threat box contains the three mediators that affect each other, and it represents their joint state.

Figure 1 captures the idea that individual- or family-level economic conditions affect populist support through subjective states that combine resentment and perception of cultural and economic vulnerability. It also advances the notion that not all economic groups are affected in the same way by macro-level factors, which include unemployment levels and trade-induced eco-

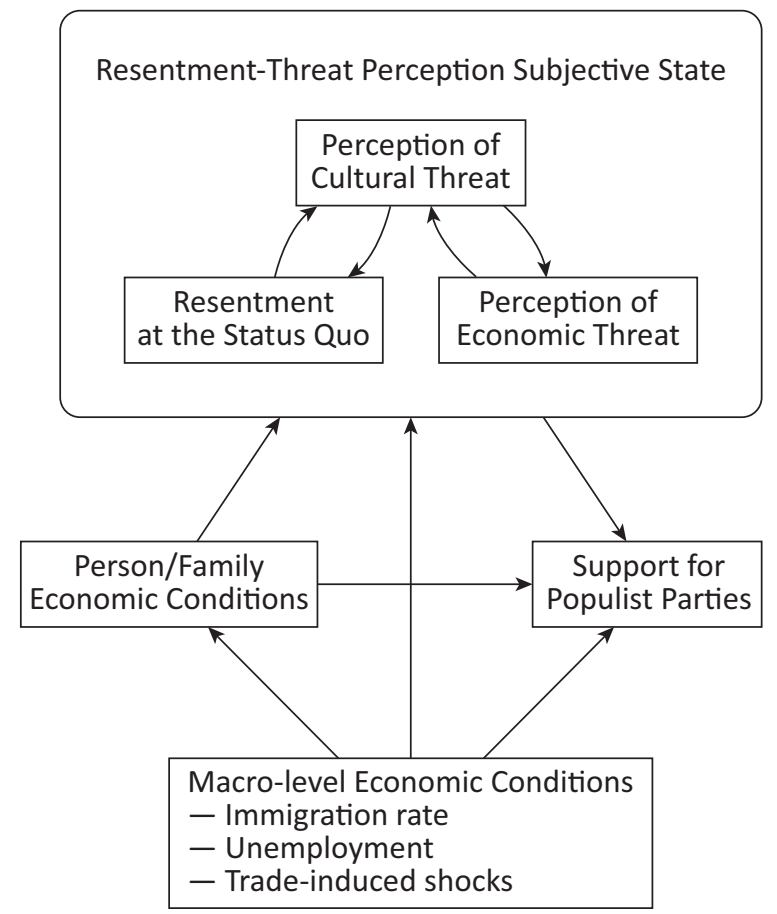

Figure 1. Causal diagram representing the hypothesis of mediated effect at the micro-level of economic conditions on populist support through resentment toward the status quo and perceptions of cultural and economic threat.

nomic shocks. It is likely, as the figure indicates, that those who are well-off economically will not have their personal economic conditions as affected as those who are more vulnerable. Hence, if we control for income when evaluating the effect of regional-level factors on populist support, we "block" one of the paths those conditions take to affect support for populism, namely, families' economic situations, and underestimate the total impact of macro-level features. On the other hand, we can control for regional-level factors and evaluate the direct and mediated effect of family income on populist vote through resentment-threat perceptions. We adopt this strategy in the empirical analysis below.

Notice that these considerations do not suggest that only low- or middle-income populations will think they are threatened economically or culturally, or feel resentful toward the status quo. Affluent populations can feel the same, and those perceptions and feelings can have an independent impact on support for populism, as many other authors have demonstrated (Capelos \& Demertzis, 2018; Capelos \& Katsanidou, 2018; Sniderman et al., 2004). The argument here says only that family and regional economic hardship conditions increase the chances that certain subjective states emerge, which are expressed in terms of resentment and perceptions of cultural and economic threat, increasing support for populists whose political positions profit electorally from those states. 


\section{Data and Methods}

\subsection{Data}

The empirical analysis is based on data from nine waves of the ESS collected biannually from 2002 to 2018. The ESS is a cross-country academically driven survey that measures attitudes, beliefs, and behavior of populations across Europe and the UK using standardized questions. The countries included in the analysis are Austria, Belgium, Switzerland, Germany, Denmark, Finland, France, the UK, Greece, Czechia, Hungary, Italy, the Netherlands, Norway, Poland, Sweden, Slovenia, and Slovakia. These are all cases in the ESS that have supporters of right-wing populist parties.

The dependent variable is vote for populist parties captured in the respondents' answer to the question about the party they voted for in the last national election, coded as 1 if the respondent voted for a right-wing populist party and 0 otherwise. The classification of parties as right-wing populists is based on Albertazzi (2008), Burgoon et al. (2018), Fella and Ruzza (2013), Mudde (2007), Rooduijn and Burgoon (2018), and Tarchi (2008). In Germany, electors have two votes and people were considered supporters of right-wing populist parties if they voted for these parties in at least one of their votes. Table 1 lists the countries and parties classified as rightwing populists.
The factors that, according to our hypothesis, mediate the effect of household-level income on populist support are resentful affect and perceptions of cultural and economic threat. We follow the previous literature to maintain comparability of this article with others' results, and select questions in the ESS that match as best as possible those underlying theoretical concepts. To capture economic threat we use an 11-point scale ESS question, asking whether the respondent perceives immigrants as good or bad for the country's economy. Cultural threat is captured using another 11-point scale question, asking if the country's cultural life is enriched or undermined by immigrants. Both variables are coded such that high values mean the respondent perceives a higher threat. Hays et al. (2019) adopted these same questions to measure xenophobic beliefs, which they use as a mediator for the effect of regional-level import shocks on vote for populism. This article complements their analysis and shows that those dimensions also work as mediators for the effect of individual-level economic conditions on populist support. Resentment against the status quo is captured in an 11-point scale ESS question that asks respondents how satisfied they are with the way democracy works in their country. Higher values mean more resentment.

As discussed above, we cannot investigate the mediation effect of resentful affect and cultural and economic threat separately or in parallel because these factors

Table 1. Right-wing populist parties in Europe.

\begin{tabular}{ll}
\hline Country & Right-Wing Populist Party \\
\hline Austria & FPÖ, BZÖ \\
Belgium & Vlaams Blok (VB), Vlaams Belang (VB), Lijst Dedecker, Démocratie Nationale \\
Czechia & Úsvit Tomia Okamury \\
Denmark & Dansk Folkeparti \\
Finland & True Finns, Finnish People's Blue-Whites \\
France & Front National (FN), Mouvement National Républicain (MNR) \\
Germany & National Democratic Party, Republikaner, Alternative for Germany (AfD) \\
Greece & Xrusi Augi (Golden Dawn), LAOS (Popular Orthodox Party) \\
Hungary & Jobbik, Fidesz \\
Italy & Forza Italia, Lega Nord, Alleanza Nazionale, Fiamma Tricolore \\
Netherlands & List Pim Fortuyn (LPF), Party for Freedom (PVV) \\
Norway & Progress Party (FRP) \\
Poland & League of Polish Families (LPR), Congress of the New Right (KNP) \\
Slovakia & Slovak National Party (SNS) \\
Slovenia & Slovene National Party (SNS), Slovenian Democratic Party (SDS) \\
Sweden & Social Democrats, Sverigedemokraterna \\
Switzerland & Swiss People's Party, Freiheits-Partei, Ticino League \\
UK & UK Independence Party, British National Party (BNP) \\
\hline
\end{tabular}

Notes: This list focuses on vote for right-wing populist parties as collected by the ESS until 2016 and reflects the sources cited in the text, but it may not portray the most-recent complete picture of right-wing populist parties in Europe. France's Front National party name changed to National Rally in 2018. 
affect each other, which can confound their association with income and populist support. Hence, instead of using them separately, we use a principal component score (PCA) created using the measurements of those dimensions. Similar analysis using these variables and principal component analysis were conducted by other authors (Sniderman et al., 2004, 2007). We call the resulting variable the threat-resentment index, and it is intended to capture the subjective state representing the three mediators jointly. The greater the value of the principal component, the greater the resentment and perception of cultural and economic threat on average. The Pearson partial correlation coefficient between the threat-resentment index and the original variables is 0.61 for resentment over how the democracy works, 0.85 for perception of cultural threat, and 0.86 for perception of economic threat. For any given value in two of these dimensions (e.g., perception of cultural and economic threat), the threat-resentment index grows linearly on the third (e.g., resentment).

The measurement of resentful affect and the threatresentment index constructed here is similar to the way Capelos and Katsanidou (2018) instrumentalize resentful and affective reactions. Hays et al. (2019) use the same question about satisfaction with the economy as in Capelos and Katsanidou (2018) but interpreted it as an indicator of sociotropic concerns of the respondent instead of resentful affect. Capelos and Katsanidou (2018) utilize this question and a series of others to create (1) a satisfaction index constructed using questions about satisfaction with life, government, democracy, and the economy, a (2) social trust index created from questions about whether the respondent trusts other people or if they believe that others always try to take advantage, and an (3) institutional trust index based on questions about trust in political institutions, government, parliament, the legal system, police, politicians, and political parties. Following Capelos and Katsanidou (2018), we create indices of satisfaction, social trust, and institutional trust using the same questions those authors selected. We compare the effect of these indices of resentment and also the threat-resentment index designed to capture a combination of threat perception (cultural and economic) and resentment.

If the argument of this article is correct, the threatresentment index should better capture the indirect (mediated) effect of a persons' economic conditions on populist support because it includes indicators of the three relevant dimensions-resentment, and cultural and economic threat-as discussed in the theoretical section.

Total household income is available in the ESS in deciles, so we use that variable as a proxy for family's economic condition. There is evidence that the social basis of right-wing populist parties in Europe are low-income, low-educated, often young and male, and often are unemployed (Arzheimer, 2009; Arzheimer \& Carter, 2006; Capelos \& Katsanidou, 2018; Evans, 2005;
Givens, 2004; Golder, 2003; Hays et al., 2019; Lubbers \& Scheepers, 2002; Lucassen \& Lubbers, 2012). Hence, following the literature, we include individual-level controls for gender, age, education, union membership, religious affiliation, unemployment, and ideology (self-placement on the left-right scale).

\subsection{Methods}

The two main quantities of interest in the article are the mediation effect of the resentment-threat index, which is composed of resentment and perceptions of cultural and economic threat, and the proportion of the effect of household economic situation on support for populism that is jointly mediated by those factors. The Supplementary File discusses the causal parameters in more detail.

\section{Results}

We start with some descriptive statistics (see Table A1 in the Supplementary File) of the raw variables employed to construct the perception and resentment indices. The proportion of votes for populist parties is around $13 \%$ in the entire sample, which contains data from 2002 to 2018. Among the dissatisfaction measures, government has the largest average, followed by the country's economy. The measure we selected to construct the resentment-threat index, dissatisfaction with the democracy, has a negative mean and median. It means that, on average, people are more satisfied than not with the way democracy works in their country. The same goes for cultural and economic threat. On average, people feel more threatened economically than culturally by immigrants.

The variables capturing perception of threat by immigrants, satisfaction, and trust in institutions or other people are all positively correlated. Figure 2 shows the pairwise correlation using Pearson's correlation coefficient between the variables used to capture those dimensions. Notice that perception of cultural and economic threat are among the pairs that show the highest positive correlations. Those two variables are also highly correlated with dissatisfaction with democracy, which is the variable this article uses as proxy for resentment toward the status quo. The only other variable that is as strongly correlated with perception of cultural and economic threat as the resentment measure is distrust in the parliament. Another interesting feature in Figure 2 is that the measures used to create the indices of dissatisfaction, social trust, and institutional trust are all strongly correlated to each other. This supports what other authors have found about those factors (Capelos \& Demertzis, 2018; Capelos \& Katsanidou, 2018; Sniderman et al., 2004, 2007).

The first component of the PCA created to summarize those dimensions captures a large portion of their variation, and the analysis indicates that one component is sufficient to represent the underlying variables. The main mediator variable instrumentalizing this 


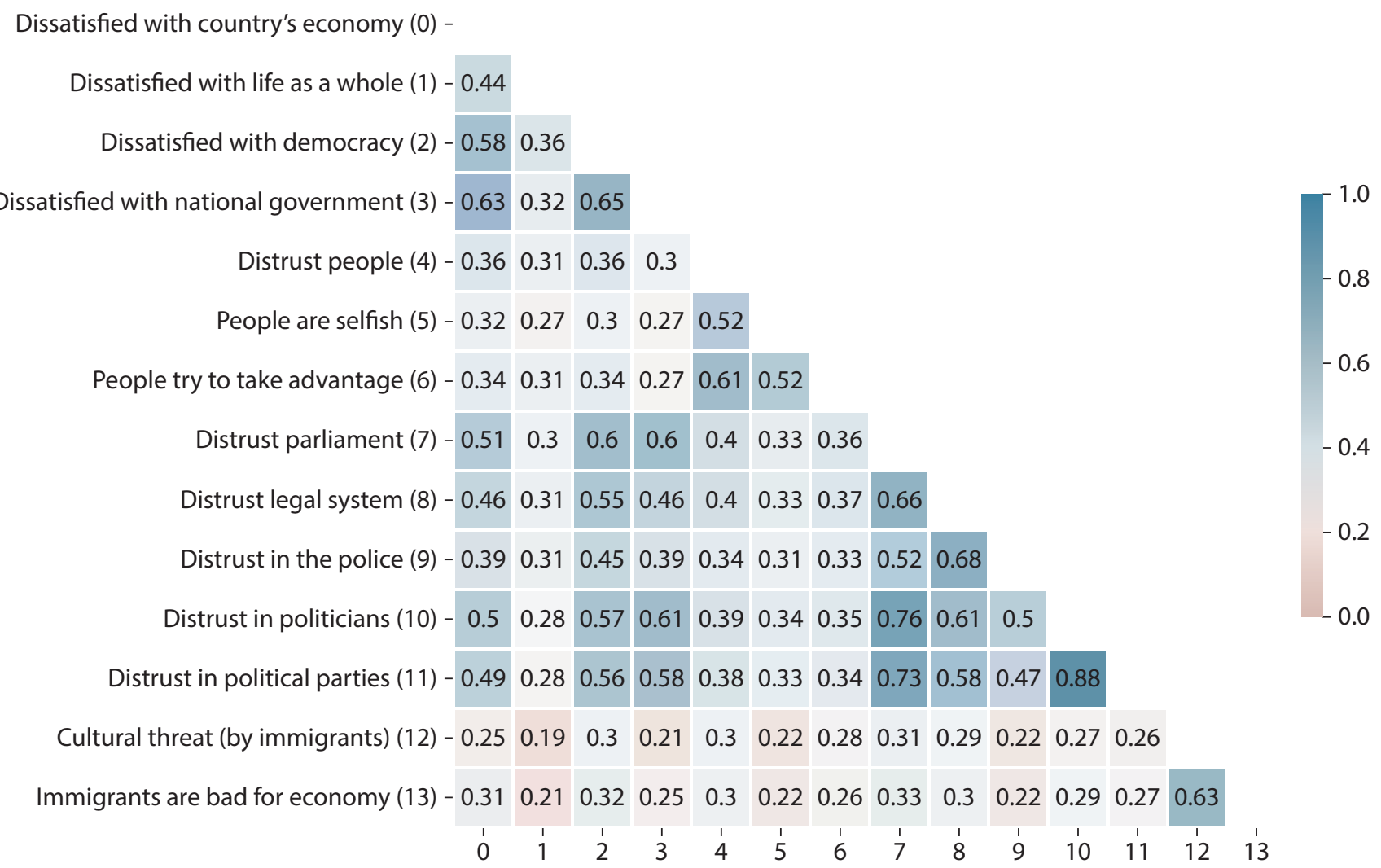

Figure 2. Pairwise correlation between measures of dissatisfaction, trust, and perceptions of cultural and economic threat.

article's theoretical argument, the resentment-threat index, created using resentment and perceptions of cultural and economic threat, captures more than $60 \%$ of the variation of the original variables. The correlation between the index and each original variables is 0.61 for resentment, 0.85 for cultural threat, and 0.86 for economic threat. Similar patterns emerged for the satisfaction, social trust, and institutional trust indices we created to contrast with the results of the resentmentthreat index.

Table 2 shows the results of a mediation analysis using the indices as mediators. It includes point estimates and confidence intervals in parentheses for eight different models divided into four groups. Each group shows the results of the analysis using different mediators. The top row indicates which mediator was used in the first and second stage regressions, as well as in the respective mediation analysis, which is based on those first and second stage results. For easy visualization, the results of the respective mediation analysis are presented in the same column of the second stage regression (rows ACME, ADE, and Proportion Mediated; see Supplementary File for the precise definition of these quantities). The second and third columns of Table 2 contain the mediator we propose, i.e., the threatresentment index, which we use to evaluate this article's core argument. We also included three other groups of columns. Each group presents results for alternative indices adopted by previous studies. We include these additional analyses so that readers can easily compare the results using the threat-resentment index against alternative constructions in the literature. In the regressions, all the variables were standardized to facilitate comparisons between the magnitude of the estimated effects, and all models include country-year random effects to account for heterogeneity at those levels.

The first stage regressions capture the first link of the causal chain connecting family-level income to populist vote through perceptions and resentment. Hence, the dependent variable in the first stage is the mediator, which by construction are PCA indices, and follows a continuous scale. The four "First Stage" columns of Table 2 show the results of linear regressions of each mediator on individuals' income and the control variables. Let us focus on the effect of income on the mediators. As expected, income has a negative effect on the mediators. It means that as income increases, the value of the threat-resentment index diminishes, which means that affluent people feel less threatened culturally and economically by immigrants, and also feel less resentful toward democracy. Comparatively, the size of the effect of income is only paralleled by education and ideology, the former having twice the effect of income. If we consider the dissatisfaction index, the effect of income is similar, but education becomes less relevant. High-income people are less dissatisfied with the economy, the way democracy works, the government, and life as a whole. The same goes for the social and institutional distrust indices. Income reduces distrust in both cases. These results indicate that perceptions, dissatisfaction, and 
trust are not randomly distributed among income groups. Resentment and perception of cultural and economic threat are more prevalent among the low-income population, as are feelings of dissatisfaction and distrust in institutions.

The columns "Second Stage" display estimates of probit hierarchical models. The models regress the dependent variable, vote for populist parties, on income, the mediators, and the individual-level controls. Let us focus on the effect of income and the mediator. As expected, as income increases, the propensity to vote for populist parties diminishes. The effect of the mediators is also as expected. Consider the threat-resentment index. The effect of that index on vote for populism is not only positive, but the largest among all the other variables considered, which echoes what other studies have found (Capelos \& Katsanidou, 2018; Hainmueller \& Hiscox, 2007, 2010; Hays et al., 2019; Sniderman et al., 2004, 2007). The more people resent the way democracy works in their country and feel threatened economically and culturally by immigrants, the more they tend to support populist parties. The second-largest effect, ideology, is the only factor included in the estimation that has a similar magnitude of the effect of the threatresentment index.

The other indexes display similar behavior. All of them have a positive effect on support for populism. People that are more dissatisfied with the democracy, economy, government, and life in general are more likely to vote for populists, as are those who have higher distrust in other people, political parties, legislature, and the political elite. Income, on the other hand, reduces those perceptions and feeling of resentment, threat, distrust, and dissatisfaction. Taken together, these results tell a story that supports the hypothesis of the mediation effect of the threat-resentment factor.

The results of the mediation analysis also supports this interpretation. The bottom part of Table 2, starting on the row ACME and ending on the row Proposition Mediated, shows the estimated quantities of direct interest for this article's argument. The column name that corresponds to the mediation results indicates the mediator used in the analysis. Consider the third column, which show the results of the mediation analysis using the threat-resentment index as mediator. The row ACME shows that income has a negative effect on vote for populist parties, as it reduces the perceptions of threat and resentment. Moreover, 55\% of the effect of income on populist support goes through that channel. The proportion of the effect of income mediated by perceptions can be as small as $46 \%$ or as large as $71 \%$. Any value on that interval would not be rejected by the analyses presented in Table 2. This represents a large share of the effect of income. It is not a surprise, then, that the effect of family-level economic conditions (e.g., income levels) becomes insignificant in some empirical analyses when one includes subjective factors, such as perceptions of threat or measures of resentment. A large part of the effect of income is not direct but mediated by those factors. So, controlling for them "blocks" some channels of communication between income and vote, obscuring some mechanisms connecting the former to the latter. When we compare with the other indices of dissatisfaction, social trust, and institutional trust, the threatresentment index mediates a larger share of the effect of income. Hence, it seems that income does affect various dimensions of satisfaction or trust, but a combination of indicators of perceptions of cultural and economic threat (Lucassen \& Lubbers, 2012) and dissatisfaction with democracy-which can turn into affective resentment with the way the political regime works in the country (Capelos \& Katsanidou, 2018)-seems to better capture the path connecting families' income and their support for populism.

It is worth noting the effect of the other variables. They corroborate our intuition and what others have found about supporters of populist parties. In all models, except two, ideology has a positive effect. People who place themselves in the right side of the left-right ideology spectrum tend to feel more resentful and threatened culturally and economically (second columns), display higher levels of social distrust (sixth column), but also feel less dissatisfied (forth column) and trust institutions more (eight column). Right-wing people are more likely to vote for populist parties, regardless of the mediator we use to control for perceptions and resentment (third, fifth, seventh, and ninth column). Authors have pointed out that populist supporters are usually male, low-educated, self-employed or unemployed, and young (Arzheimer, 2009; Evans, 2005; Givens, 2004; Golder, 2016; Lubbers \& Scheepers, 2002; Lucassen \& Lubbers, 2012). Table 2 echoes those findings. Age reduces perception of threat, dissatisfaction, and support for populist parties, and so does years of education, which has a large magnitude of effect when compared to other variables in many models. The negative effect of gender shows that women are less likely to support populist parties (Givens, 2004), but they are more resentful with the way democracy works and feel more threatened economically and culturally than men. They also have less social distrust, but more institutional distrust. As expected, the unemployed feel more threatened and are more likely to support populist parties, and so do those who are or were members of unions. Even though the analysis does not differentiate between religious denominations, we see that, on average, religious affiliation in Europe diminishes the inclination to vote for populists, the feelings of resentment toward democracy, and the feelings of being culturally and economically threatened by immigrants.

For the mediation effect found in Table 2 to have a causal interpretation, sequential ignorability must hold. In the context of the analysis in Table 2, it means, first, that household income is not affected by the threat-resentment index or support for populist parties, given the controls. This condition would be violated if, for instance, a persons' household was determined 
Table 2. Effect of income on vote for right-wing populist parties through its effect on resentment and perceptions of cultural and economic threat.

\begin{tabular}{|c|c|c|c|c|c|c|c|c|}
\hline & \multicolumn{2}{|c|}{ Threat/resentment index (TRI) } & \multicolumn{2}{|c|}{ Dissatisfaction index (DI) } & \multicolumn{2}{|c|}{ Social distrust index (SDI) } & \multicolumn{2}{|c|}{ Distrust in institutions index (DII) } \\
\hline & First Stage & Second Stage & First Stage & Second Stage & First Stage & Second Stage & First Stage & Second Stage \\
\hline Income & $\begin{array}{c}-109 \\
(-0.1157,-0.1024)\end{array}$ & $\begin{array}{c}-0.0678 \\
(-0.0979,-0.0377)\end{array}$ & $\begin{array}{c}-0.1405 \\
(-0.1466,-0.1344)\end{array}$ & $\begin{array}{c}-0.0625 \\
(-0.092,-0.033)\end{array}$ & $\begin{array}{c}-0.0939 \\
(-0.1003,-0.0875)\end{array}$ & $\begin{array}{c}-0.1167 \\
(-0.1454,-0.0879)\end{array}$ & $\begin{array}{c}-0.0936 \\
(-0.1,-0.0873)\end{array}$ & $\begin{array}{c}-0.0966 \\
(-0.1258,-0.0674)\end{array}$ \\
\hline TRI & & $\begin{array}{c}0.7739 \\
(0.7423,0.8055)\end{array}$ & & & & & & \\
\hline DI & & & & $\begin{array}{c}0.5815 \\
(0.5482,0.6148)\end{array}$ & & & & \\
\hline SDI & & & & & & $\begin{array}{c}0.3335 \\
(0.3029,0.3641)\end{array}$ & & \\
\hline DII & & & & & & & & $\begin{array}{c}0.5451 \\
(0.513,0.5771)\end{array}$ \\
\hline Ideology & $\begin{array}{c}0.1145 \\
(0.1085,0.1205)\end{array}$ & $\begin{array}{c}752 \\
(0.723,0.7809)\end{array}$ & $\begin{array}{c}-0.1145 \\
(-0.1199,-0.109)\end{array}$ & $\begin{array}{c}0.8786 \\
(0.8496,0.9075)\end{array}$ & $\begin{array}{c}0.0249 \\
(0.0192,0.0306)\end{array}$ & $\begin{array}{c}0.8098 \\
(0.7818,0.8378)\end{array}$ & $\begin{array}{c}-24 \\
(-0.0296,-0.0183)\end{array}$ & $\begin{array}{c}0.8404 \\
(0.8119,0.8689)\end{array}$ \\
\hline Age & $\begin{array}{c}-0.0022 \\
(-0.0091,0.0046)\end{array}$ & $\begin{array}{c}-0.1629 \\
(-0.1932,-0.1326)\end{array}$ & $\begin{array}{c}-0.0039 \\
(-0.0102,0.0023)\end{array}$ & $\begin{array}{c}-0.1753 \\
(-0.2051,-0.1455)\end{array}$ & $\begin{array}{c}-0.0461 \\
(-0.0527,-0.0396)\end{array}$ & $\begin{array}{c}-158 \\
(-0.1871,-0.1289)\end{array}$ & $\begin{array}{c}0.0115 \\
(0.005,0.0181)\end{array}$ & $\begin{array}{c}-0.1804 \\
(-0.21,-0.1508)\end{array}$ \\
\hline Education & $\begin{array}{c}-0.2106 \\
(-0.2171,-0.2042)\end{array}$ & $\begin{array}{c}-0.2535 \\
(-0.2842,-0.2228)\end{array}$ & $\begin{array}{c}-0.0585 \\
(-0.0644,-0.0526)\end{array}$ & $\begin{array}{c}-0.3563 \\
(-0.3858,-0.3269)\end{array}$ & $\begin{array}{c}-0.0993 \\
(-0.1055,-0.0931)\end{array}$ & $\begin{array}{c}-0.3599 \\
(-0.389,-0.3308)\end{array}$ & $\begin{array}{c}-0.0973 \\
(-0.1034,-0.0912)\end{array}$ & $\begin{array}{c}-0.3437 \\
(-0.3732,-0.3142)\end{array}$ \\
\hline Female & $\begin{array}{c}0.0278 \\
(0.0157,0.0399)\end{array}$ & $\begin{array}{c}-0.2817 \\
(-0.3361,-0.2274)\end{array}$ & $\begin{array}{c}0.0431 \\
(0.0321,0.0542)\end{array}$ & $\begin{array}{c}-0.2763 \\
(-0.3296,-0.223)\end{array}$ & $\begin{array}{c}-0.0695 \\
(-0.0811,-0.0579)\end{array}$ & $\begin{array}{c}-0.2268 \\
(-0.2792,-0.1744)\end{array}$ & $\begin{array}{c}0.03 \\
(0.0185,0.0415)\end{array}$ & $\begin{array}{c}-0.2572 \\
(-0.3103,-0.2042)\end{array}$ \\
\hline Unemployed & $\begin{array}{c}0.0785 \\
(0.044,0.1129)\end{array}$ & $\begin{array}{c}0.0286 \\
(-0.1207,0.1778)\end{array}$ & $\begin{array}{c}0.2727 \\
(0.2413,0.3041)\end{array}$ & $\begin{array}{c}-0.0714 \\
(-0.2172,0.0744)\end{array}$ & $\begin{array}{c}0.1399 \\
(0.107,0.1728)\end{array}$ & $\begin{array}{c}0.0359 \\
(-0.1073,0.1791)\end{array}$ & $\begin{array}{c}0.1108 \\
(0.0782,0.1435)\end{array}$ & $\begin{array}{c}52 \\
(-0.0925,0.1965)\end{array}$ \\
\hline Religion & $\begin{array}{c}-0.0258 \\
(-0.0387,-0.0129)\end{array}$ & $\begin{array}{c}-0.2254 \\
(-0.2836,-0.1671)\end{array}$ & $\begin{array}{c}-113 \\
(-0.1248,-0.1012)\end{array}$ & $\begin{array}{c}-174 \\
(-0.2311,-0.1169)\end{array}$ & $\begin{array}{c}-0.0252 \\
(-0.0376,-0.0128)\end{array}$ & $\begin{array}{c}-0.2292 \\
(-0.2853,-0.1732)\end{array}$ & $\begin{array}{c}-0.1336 \\
(-0.1459,-0.1214)\end{array}$ & $\begin{array}{c}-0.1702 \\
(-0.2271,-0.1134)\end{array}$ \\
\hline Union & $\begin{array}{c}0.0359 \\
(0.0219,0.0498)\end{array}$ & $\begin{array}{c}0.1252 \\
(0.0628,0.1876)\end{array}$ & $\begin{array}{c}0.0662 \\
(0.0535,0.079)\end{array}$ & $\begin{array}{c}0.1151 \\
(0.0541,0.1761)\end{array}$ & $\begin{array}{c}0.0113 \\
(-0.002,0.0246)\end{array}$ & $\begin{array}{c}0.1467 \\
(0.0868,0.2066)\end{array}$ & $\begin{array}{c}0.0287 \\
(0.0154,0.0419)\end{array}$ & $\begin{array}{c}0.1364 \\
(0.0757,0.1971)\end{array}$ \\
\hline ACME & & $\begin{array}{c}-0.0058 \\
(-0.0073,-0.0045)\end{array}$ & & $\begin{array}{c}-0.0059 \\
(-0.0074,-0.0045)\end{array}$ & & $\begin{array}{c}-0.0023 \\
(-0.003,-0.0018)\end{array}$ & & $\begin{array}{c}-0.0037 \\
(-0.0046,-0.0028)\end{array}$ \\
\hline ADE & & $\begin{array}{c}-0.0047 \\
(-0.0071,-0.0024)\end{array}$ & & $\begin{array}{c}-0.0045 \\
(-0.0071,-0.0023)\end{array}$ & & $\begin{array}{c}-0.0086 \\
(-0.0118,-0.0061)\end{array}$ & & $\begin{array}{c}-0.0069 \\
(-0.0096,-0.0046)\end{array}$ \\
\hline $\begin{array}{l}\text { Proportion } \\
\text { Mediated }\end{array}$ & & $\begin{array}{c}0.553 \\
(0.4602,0.7064)\end{array}$ & & $\begin{array}{c}0.5657 \\
(0.4681,0.7048)\end{array}$ & & $\begin{array}{c}0.2124 \\
(0.171,0.2657)\end{array}$ & & $\begin{array}{c}0.3473 \\
(0.2825,0.4378)\end{array}$ \\
\hline RE (Ctr+Year) & $x$ & $x$ & $x$ & $x$ & $x$ & $x$ & $x$ & $\mathrm{X}$ \\
\hline Adj./Pseudo R2 & 0.2626 & 0.5206 & 0.3645 & 0.4975 & 0.2344 & 0.4931 & 0.2911 & 0.5046 \\
\hline
\end{tabular}


by their attitudes toward immigrants or populist parties, which seems implausible. Another possibility is that there are unobserved confounders affecting both income and resentment-threat perceptions. Macro-level factors, such as economic shock, unemployment rate, and influx of immigrants can work as confounders in this case. Second, another identification condition is that vote for populist parties and resentment-threat perceptions are independent, given income and the other covariates. As before, this condition could be violated if people become resentful and feel threatened, because they would potentially vote for the populist party under some economic conditions and subjective states, which again seems implausible. But it could be the case if the parties inculcate resentment and feelings of insecurity that would not exist otherwise. Another possibility is that there are omitted factors causing both vote for populist parties and resentment-threat perception, such as macrolevel import economic shocks (Hays et al., 2019). To deal with this possibility, we repeat the analysis of Table 2 for 2016 only, due to data availability, and include variables capturing those macro-level factors.

Table A2 in the Supplementary File shows the results of the analysis after controlling for macro-level variables measured at the NUTS 1 level as in Hays et al. (2019). The controls include economic growth rate, region and countries' population, region population density, region's unemployment rate in the current year, as well as 1 and 5 years ago, trade balance, inflow of immigrants, and trade-induced import shock. Inflow of immigrants is the change in the ratio of immigrants at the NUTS 2 level from 2001 to 2011. For details of the other variables see Hays et al. (2019). Table A2 also shows the proper test for the hypothesis that resentment-threat mediates the effect of household income on support for populist parties, depicted in the diagram of Figure 1. All results presented on the second and third columns of Table 2 hold when regional controls are included. The effect of resentment-threat is larger on populist votes than in all models of Table 2. When we take into account regional factors, $41.1 \%$ of the effect of household income on populist support is mediated by its effect on resentment and perceptions that immigrants pose an economic and cultural threat to the country. The confidence interval ranges from $28 \%$ to $70 \%$. Even in the lower end of the interval, the mediated effect is large.

\section{Final Discussion}

Support for right-wing populist parties has grown in various European countries in the last decades (Rooduijn et al., 2019). From a normative perspective, on the supply side this can be a reason for concern to the extent that right-wing populists represent a threat to democratic institutions. They represent a threat for a few reasons. First, their discourse depicts the political institutions and democratic procedures, such as general elections, as dysfunctional, corrupted, and manipulated by self-serving mainstream parties. The solution rightwing populists propose are not through a democratic process and institutional remedies, but through an elected outsider leader who represents the voice of "the people" against the old and corrupted political elite. Second, they often use otherizing tactics to picture some social groups as a threat to the "good people," denying voice and political rights to minorities and some social groups. So, anyone opposing those ideas are accused to be "against the good people's interest." Third, these leaders often appropriate the meaning of nationalism and equate it with their political agenda. Hence, anyone against their positions is accused to be against the "homeland." Finally, right-wing populists often try to undermine free press by accusing them of promoting fake news. Although the intensity of these supply-side features of right-wing populist parties vary by country, many are common to one degree or another across borders, in particular the opposition of "the people" against the political elite and established institutions. Despite of that variation, right-wing parties can represent a threat, in sum, by disregarding the democratic institutions and their rituals, denying political voice to social groups, appropriating the meaning of nationalism, and trying to undermine free press.

The question is why and how these parties find support for their ideas among the electorate. On the demand side of right-wing populist politics, this article provided evidence of a mediating mechanism connecting families' economic conditions, captured empirically using families' income, and vote for right-wing populists. On average, across European countries, families' economic situations affect populism because as their financial security declines, people are more likely to resent the way democracy works and perceive immigrants as an economic and cultural threat to the country. As resentment and perception of threat increases, the chances to vote for right-wing populists also increases.

The analysis conducted here has some limitations but also points to some opportunities for extensions and future research. One limitation is how the article operationalizes families' economic conditions, using familylevel income in deciles. The distinction is between theoretical and empirical concepts. The analyses use family income as a proxy for economic conditions. This is a restriction imposed by the available data, because family income in deciles is promptly available in the ESS. But there is no reason for restricting the theoretical discussion due to the limitations imposed by available proxies. Others may operationalize that concept of family economic conditions differently and provide additional evidence for or against the argument. Along those lines, possible extensions involve expanding the set of concrete circumstances that can affect perceptions and emotions that mediate the effect of those circumstances on support for right-wing parties, such as schooling or race. Other extensions can include other mediators. Authors have shown, for instance, that anger affects support for right-wing populism (Mayer \& Nguyen, 2021). Others 
show that low-income groups tend to perceive that the government is unresponsive (Droste, 2021), which can reinforce the findings presented here.

Another limitation is that the analyses in the article use only observational data. The article adopted as part of its identification strategy an aggregated index constructed from mutually causal related mediators, but future research can further investigate the theoretical argument to leverage causal interpretations using other identification strategies, such as experimental designs. Finally, the focus of this article is on the vote for right-wing populists, but next steps involve investigating whether similar mechanisms can explain support for left-wing populist parties and, if not, how they differ and why.

These results suggests that if right-wing populism were a threat to democracy, that threat will be echoed and supported by public opinion to the extent that perceptions of threat and resentment increases and are fueled by a decline in families' economic conditions. Hence, to attenuate the public anti-attitudes (antiimmigrants, anti-democratic institutions, anti-parties, anti-minority groups) that can lead to unjustifiable discrimination against some social groups and threaten democratic institutions and inclusiveness, one can act directly at the cognitive and affective levels and try to assuage resentment and persuade people that other groups are not a threat. But because real economic conditions at the family-level fuel those perceptions and feelings, that strategy may not be sufficient. It will work more effectively if accompanied by measures to mitigate concrete conditions that can lead families to economic hardship.

\section{Acknowledgments}

I thank the editors and reviewers of the manuscript for their insightful comments.

\section{Conflict of Interests}

The author declares no conflict of interests.

\section{Supplementary Material}

Supplementary material for this article is available online in the format provided by the author (unedited).

\section{References}

Albertazzi, D. (2008). Switzerland: Yet another populist paradise. In D. Albertazzi \& D. Mcdonnell (Eds.), Twenty-first century populism: The spectre of Western European democracy (pp. 84-99). Palgrave Macmillan.

Arzheimer, K. (2009). Contextual factors and the extreme right vote in Western Europe, 1980-2002. American Journal of Political Science, 53(2), 259-275.
Arzheimer, K., \& Carter, E. (2006). Political opportunity structures and right-wing extremist party success. European Journal of Political Research, 45(3), 419-443.

Betz, H. (1993). The new politics of resentment: Radical right-wing populist parties in Western Europe. Comparative politics, 25, 413-427.

Betz, H. (1994). Radical right-wing populism in Western Europe. Springer.

Betz, H. (2009). Xenophobia, identity politics and exclusionary populism in Western Europe. Socialist Register, 39, 193-211.

Blalock, H. M. (1967). Toward a theory of minority-group relations. Wiley.

Burgoon, B., van Noort, S., Rooduijn, M., \& Underhill, G. (2018). Positional deprivation and support for radical right and radical left parties. Economic Policy, 34(97), 49-93.

Capelos, T., \& Demertzis, N. (2018). Political action and resentful affectivity in critical times. Humanity \& Society, 42(4), 410-433.

Capelos, T., \& Katsanidou, A. (2018). Reactionary politics: Explaining the psychological roots of anti preferences in European integration and immigration debates. Political Psychology, 39(6), 1271-1288.

Colantone, I., \& Stanig, P. (2018). The trade origins of economic nationalism: Import competition and voting behavior in Western Europe. American Journal of Political Science, 62(4), 936-953.

Colantone, I., \& Stanig, P. (2019). The surge of economic nationalism in Western Europe. Journal Of Economic Perspectives, 33(4), 128-151.

Coser, L. A. (1956). The functions of social conflict Glencoe.

Demertzis, N. (2006). Emotions and populism. In S. Clarke, P. Hoggett, \& S. Thompson (Eds.), Emotion, politics and society (pp. 103-122). Springer.

Droste, L. (2021). Feeling left behind by political decisionmakers: Anti-establishment sentiment in contemporary democracies. Politics and Governance, 9(3), 288-300.

Evans, J. A. (2005). The dynamics of social change in radical right-wing populist party support. Comparative European Politics, 3(1), 76-101.

Fella, S., \& Ruzza, C. (2013). Populism and the fall of the centre-right in Italy: The end of the Berlusconi model or a new beginning? Journal of Contemporary European Studies, 21(1), 38-52.

Givens, T. E. (2004). The radical right gender gap. Comparative Political Studies, 37(1), 30-54.

Golder, M. (2003). Explaining variation in the success of extreme right parties in Western Europe. Comparative Political Studies, 36(4), 432-466.

Golder, M. (2016). Far right parties in Europe. Annual Review of Political Science, 19, 477-497.

Hainmueller, J., \& Hiscox, M. J. (2007). Educated preferences: Explaining attitudes toward immigration in Europe. International Organization, 61(2), 399-442. 
Hainmueller, J., \& Hiscox, M. J. (2010). Attitudes toward highly skilled and low-skilled immigration: Evidence from a survey experiment. American Political Science Review, 104(1), 61-84.

Hardin, R. (1997). One for all: The logic of group conflict. Princeton University Press.

Hays, J., Lim, J., \& Spoon, J. J. (2019). The path from trade to right-wing populism in Europe. Electoral Studies, 60. https://doi.org/10.1016/j.electstud.2019.04.002

Inglehart, R. (1997). Modernization and postmodernization: Cultural, economic, and political change in 43 societies. Cambridge University Press.

Ivarsflaten, E. (2005). The vulnerable populist right parties: No economic realignment fuelling their electoral success. European Journal of Political Research, 44(3), 465-492.

Ivarsflaten, E. (2008). What unites right-wing populists in Western Europe? Re-examining grievance mobilization models in seven successful cases. Comparative Political Studies, 41(1), 3-23.

Koopmans, R., Statham, P., Giugni, M., \& Passy, F. (2005). Contested citizenship: Immigration and cultural diversity in Europe. University of Minnesota Press.

Lubbers, M., Gijsberts, M., \& Scheepers, P. (2002). Extreme right-wing voting in Western Europe. European Journal of Political Research, 41(3), 345-378.

Lubbers, M., \& Scheepers, P. (2002). French Front National voting: A micro and macro perspective. Ethnic and Racial Studies, 25(1), 120-149.

Lucassen, G., \& Lubbers, M. (2012). Who fears what? Explaining far-right-wing preference in Europe by distinguishing perceived cultural and economic ethnic threats. Comparative Political Studies, 45(5), 547-574.

Margalit, Y. (2019). Economic insecurity and the causes of populism, reconsidered. Journal Of Economic Perspectives, 33(4), 152-170.

Mayda, A. M. (2006). Who is against immigration? A cross-country investigation of individual attitudes toward immigrants. The Review Of Economics And Statistics, 88(3), 510-530.

Mayer, S. J., \& Nguyen, C. G. (2021). Angry reactionary narcissists? Anger activates the link between narcissism and right-populist party support. Politics and Governance, 9(3), 248-259.

Minkenberg, M. (2000). The renewal of the radical right: Between modernity and anti-modernity. Government and Opposition, 35(2), 170-188.

Mudde, C. (2007). Populist radical right parties in Europe. Cambridge University Press.

Mudde, C. (2010). The populist radical right: A pathological normalcy. West European Politics, 33(6), 1167-1186.

Mudde, C., \& Kaltwasser, C. R. (2017). Populism: A very short introduction. Oxford University Press.

Mutz, D. C. (2018). Status threat, not economic hardship, explains the 2016 presidential vote. Proceedings of the National Academy of Sciences, 115(19),
4330-4339.

Norris, P. (2005). Radical right: Voters and parties in the electoral market. Cambridge University Press.

Park, S., \& Esterling, K. M. (2020). Sensitivity analysis for pretreatment confounding with multiple mediators. Journal of Educational and Behavioral Statistics, 46(1), 85-108.

Rodrik, D. (2018). Populism and the economics of globalization. Journal Of International Business Policy, 1(1/2), 12-33.

Rooduijn, M., \& Burgoon, B. (2018). The paradox of wellbeing: Do unfavorable socioeconomic and sociocultural contexts deepen or dampen radical left and right voting among the less well-off? Comparative Political Studies, 51(13), 1720-1753.

Rooduijn, M., Van Kessel, S., Froio, C., Pirro, A., De Lange, S., Halikiopoulou, D., Lewis, P., Mudde, C., \& Taggart, P. (2019). The PopuList: An overview of populist, far right, far left and Eurosceptic parties in Europe [Data set]. The PopuList. https://popu-list.org

Rydgren, J., \& Ruth, P. (2013). Contextual explanations of radical right-wing support in Sweden: Socioeconomic marginalization, group threat, and the halo effect. Ethnic and Racial Studies, 36(4), 711-728.

Scheepers, P., Gijsberts, M., \& Coenders, M. (2002). Ethnic exclusionism in European countries. Public opposition to civil rights for legal migrants as a response to perceived ethnic threat. European Sociological Review, 18(1), 17-34.

Semyonov, M., Raijman, R., \& Gorodzeisky, A. (2006). The rise of anti-foreigner sentiment in European societies, 1988-2000. American Sociological Review, 71(3), 426-449.

Semyonov, M., Raijman, R., Tov, A. Y., \& Schmidt, P. (2004). Population size, perceived threat, and exclusion: A multiple-indicators analysis of attitudes toward foreigners in Germany. Social Science Research, 33(4), 681-701.

Sniderman, P. M., Hagendoorn, L., \& Hagendoorn, A. (2007). When ways of life collide: Multiculturalism and its discontents in the Netherlands. Princeton University Press.

Sniderman, P. M., Hagendoorn, L., \& Prior, M. (2004). Predisposing factors and situational triggers: Exclusionary reactions to immigrant minorities. American Political Science Review, 98(1), 35-49.

Tajfel, H., \& Turner, J. C. (2004). An integrative theory of intergroup conflict. In M. J. Hatch \& M. Schultz (Eds.), Organizational identity: A reader (pp. 56-65). Oxford University Press.

Tarchi, M. (2008). Italy: A country of many populisms. In D. Albertazzi \& D. Mcdonnell (Eds.), Twenty-first century populism: The spectre of Western European democracy (pp. 84-99). Palgrave Macmillan.

Turner, J. C., \& Tajfel, H. (1986). The social identity theory of intergroup behavior. In S. Worchel \& W. G. Austin (Eds.), Psychology of intergroup relations (pp. 7-24). Nelson-Hall. 
Werts, H., Scheepers, P., \& Lubbers, M. (2013). Euroscepticism and radical right-wing voting in Europe, 2002-2008: Social cleavages, socio-political attitudes and contextual characteristics determining voting for the radical right. European Union Politics, 14(2), 183-205.

\section{About the Author}

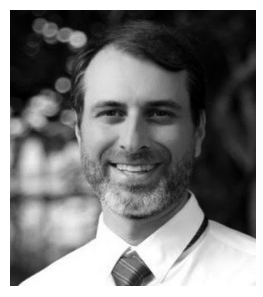

Diogo Ferrari is Assistant Professor of political science at the University of California, Riverside. His research combines political economy and political psychology and is centered on the relationship between economic conditions, perceptions, attitude formation, and political behavior. His work on political methodology focuses on causal inference, semi-parametric Bayesian methods, and unsupervised learning. His research has appeared in journals such as Political Analysis, Publius, and Critical Review. 